\title{
RELEVANSI NILAI SERTA IMPLIKASI RISIKO ATAS KEUNTUNGAN DAN KERUGIAN PERUBAHAN NILAI WAJAR KEWAJIBAN PERBANKANDI INDONESIA
}

\author{
Dewa Ayu Diah Pramiari ${ }^{1}$, Raden Bagus Faizal Irany Sidharta ${ }^{2}$ \\ ${ }^{1}$ Fakultas Ekonomi dan Bisnis, Universitas Mataram, pramiary@gmail.com \\ ${ }^{2}$ Fakultas Ekonomi dan Bisnis, Universitas Mataram, ronyfaizal93@gmail.com
}

\begin{abstract}
ABSTRAK
Penelitian ini bertujuan untuk menguji pengaruh keuntungan dan kerugian atas perubahan nilai wajar dari instrument hutang, EPS, dan laba setelah keuntungan/kerugian atas perubahan nilai dari instrument hutang terhadap return saham dan pengaruh laba setelah keuntungan/kerugian atas perubahan nilaidari instrument hutang dan laba bersih terhadap beta return. Pengujian dilakukan pada 23 perusahaan bank umum devisa karena bank umum devisa merupakan perusahaan yang memiliki akuntabilitas publik signifikanyang terdaftar di Bursa Efek Indonesia. Penelitian ini menggunakan dua model yang diuji dengan analisis regresi linear berganda. Hasil regresi pertama menemukan bahwa keuntungan /kerugian atas perubahan nilai dari instrument hutang, laba setelah keuntungan/kerugian atas perubahan nilai dari instrument hutang, dan EPS berpengaruh secara simultan terhadap return saham. Secara parsial hanya EPS berpengaruh positif terhadap return saham. Hasil regresi kedua menemukan bahwa laba setelah keuntungan/ kerugian atas perubahan nilai dari instrument hutang dan laba bersih tahun berjalan tidak berpengaruh secara simultan terhadap beta return. Secara parsial laba bersih tahun berjalan berpengaruh positif terhadap beta return.
\end{abstract}

Kata kunci: nilai wajar, laba bersih, return saham, beta return.

\section{ABSTRACT}

This study aims to examine the influence of gains and losses on changes in fair value of debt instruments, EPS, and earnings after gain/loss on change in value of debt instruments on stock returns. This study also aims to examine the influence of net income after gains/losses of changes in the fair value of debt instruments and net income to beta return. Analyses were conducted on 23 foreign exchange banks since these foreign exchange banks are company that has public significant accountability and listed on the Indonesia Stock Exchange. This study used two models which were analyzed by multiple linear regression analysis. The first regression results found that gains/losses on changes in the value of debt instruments, net income after gain/ loss on change in fair value of the debt instrument, and EPS simultaneously affect stock returns. However, only EPS that has partial and positive effect on stock returns. The second regression results found that net income after gain/loss on change in fair value of debt instruments and net income of the current year has no simultaneous effect to the beta return, while net income for the year partially and positively affect the beta return.

Keywords: fair value, net income, stock returns, beta return.

\section{PENDAHULUAN}

Laporan keuangan merupakan bagian yang sangat penting bagi suatu perusahaan, terlebih jika perusahaan tersebut merupakan perusahaan go public. Perusahaan go publicmenggunakan PSAKsebagai standar laporan keuangannya. Agar suatu laporan keuangan dapat memenuhi tujuan laporan keuangan sesuai dengan yang disebutkan dalam PSAK, maka perlu memerhatikan karakteristik kualitatif atau ciri khas yang membuat informasi dalam laporan keuangan tersebut berguna bagi 
penggunanya. Standar akuntansi keuangan menyebutkan terdapat empat karakteristik kualitatif pokok, yaitu: dapat dipahami, relevan, keandalan, dan dapat diperbandingkan.Pernyataan Standar Akuntansi Keuangan (PSAK) No 50 tentang Instrumen Keuangan: Penyajian menyebutkan nilai wajar adalah jumlah suatu aset dipertukarkan, atau liabilitas diselesaikan, antara pihak-pihak yang berkeinginan dan memiliki pengetahuan memadai dalam suatu transaksi yang wajar.Hal ini senada dengan yang diungkapkan dalam IFRS 13 tentang Fair Value Measurement yang mendefinisikan nilai wajar sebagai harga yang akan diterima untuk menjual aset atau dibayar untuk mentransfer kewajiban dalam transaksi teratur antara pelaku pasar pada tanggal pengukuran (yaitu harga exit).

Menurut Wibisana (2009) dalam Hardiani (2014) fair value mempunyai keunggulan, dengan menggunakan konsep ini laporan keuangan menjadi lebih relevan untuk dasar pengambilan keputusan, dan dengan konsep ini, laporan keuangan dapat diperbandingkan, serta informasi mendekati keinginan pemakai laporan keuangan. Hasil penelitian Hardiani (2014) mengemukakan bahwa penggunaan fair value sebagai basis penilaian dalam pelaporan keuangan dapat meningkatkan relevansi pelaporan keuangan. Nilai wajar dinilai lebih dapat mencerminkan nilai aset atau liabilitas sesuai kondisi yang sebenarnya. Financial Accounting Standard Board (FASB) telah mengidentifikasi nilai wajar sebagai yang paling relevan. Dasar pengukuran instrumen keuangan telah menunjukkan bahwa mengukur semua keuangan instrumen pada nilai wajar merupakan salah satu tujuan jangka panjang. Mereka yang setuju dengan tujuan FASB percaya mengukur kewajiban pada nilai wajar konsisten dengan pengukuran aset pada nilai wajar. Barth et al(2008) menyebutkan tujuan FASB juga konsisten dengan pendapatan dan volatilitas yang lebih baik mencerminkan pasar dan risiko lainnya ketika perusahaan mengukur aset dan kewajiban keuangan pada nilai wajar.

PSAK No. 50 mengungkapkan bahwa informasi nilai wajar dapat digunakan untuk tujuan bisnis dalam menentukan posisi keuangan entitas secara keseluruhan dan dalam pengambilan keputusan mengenai instrumen keuangan. Informasi tersebut juga relevan terhadap berbagai keputusan yang diambil oleh pengguna laporan keuangan. Penelitian ini lebih melihat pada perspektif investor, yaitu bagaimana investor melihat relevansi nilai perusahaan dilihat dari besarnya return saham dan risiko perusahaan tersebut.

Earning per share (EPS) merupakan rasio yang menggambarkan tingkat laba yang diperoleh oleh para pemegang saham, dimana tingkat laba (per lembar saham) menunjukkan kinerja perusahaan terutama dari kemampuan laba yang dikaitkan dengan pasar. EPS menunjukkan bahwa semakin besar tingkat kemampuan perusahaan dalam menghasilkan keuntungan per lembar saham bagi pemiliknya, maka hal akan mempengaruhi return saham perusahaan tersebut di pasar modal.

Pernyataan Standar Akuntansi Keuangan (PSAK) merupakan standar yang digunakan untuk menyusun laporan keuangan perusahaan yang memiliki akuntabilitas publik signifikan (Martani, 2011). Bank umum devisa termasuk perusahaan yang memiliki akuntabilitas publik signifikan karena laporannya diberikan kepada masyarakat. Bank umum devisa ini juga merupakan salah satu sektor yang patuh menerapkan nilai wajar untuk akun liabilitasnya menurut aturan yang telah ditetapkan PSAK.

Menurut Pedoman Akuntansi Perbankan Indonesia (PAPI) (2008), kewajiban keuangan dan kewajiban lainnya diukur pada nilai wajar melalui laporan laba rugi. Nilai wajar aset atau kewajiban mencerminkan kondisi pasar saat ini dan memberikan 
informasi yang tepat waktu, sehingga meningkatkan transparansi dan mendorong tindakan korektif dengan cepat.

Penelitian yang dilakukan oleh Hodder (2005) yang meneliti tentang relevansi dan risiko atas tindakan nilai wajar pendapatan bagi bank umum. Penelitian ini menyelidiki relevansi risiko standar deviasi dari tiga ukuran kinerja, yaitu: laba bersih, pendapatan komprehensif, dan pendapatan atas penggunaan nilai wajar penuh (full fair value income) dengan sampel 202 bank komersial AS dari tahun 1996 sampai 2004..Hasil dari penelitian ini diketahui bahwa volatilitas dari pendapatan atas penggunaan nilai wajar penuh secara signifikan lebih besar dari volatilitas laba bersih dan laba komprehensif untuk keseluruhan sampel bank yang digunakan.

Penelitian yang dilakukan oleh Barthet al. (2008) yang meneliti tentang nilai wajar akuntansi kewajiban dan resiko kredit sendiri. Hasil dari penelitian ini diketahui bahwa pengembalian ekuitas berpengaruh negatif dan signifikan terkait dengan perubahan risiko kredit. Penelitian ini juga menemukan bahwa hubungan antara perubahan risiko kredit dan pengembalian ekuitas secara signifikan kurang negatif ketika perusahaan memiliki lebih banyak utang.

Lim et al. (2011) dalam penelitiannya mengenai risiko bank dan relevansi nilai dari keuntungan kerugian dari nilai wajar bank. Hasil dari penelitian ini diketahui bahwa keuntungan dan kerugian relevansi nilai wajar memiliki nilai positif berhubungan dengan tingkat risiko bank sebelum krisis. Selama krisis, ada beberapa bukti hubungan positif yang sama tetapi hasilnya lebih lemah mengingat risiko lingkungan yang berubah. Selain itu kami menemukan bahwa nilai wajar keuntungan/kerugian dari bank yang memilih untuk menggunakan opsi nilai wajar aset yang bisa diperhitungkan di hal biaya perolehan diamortisasi adalah nilai lebih relevan dan gigih.Dari sudut pandang kebijakan hasilnya menunjukkan bahwa keuntungan nilai wajar dan kerugian bank harus terpisah dan dipertanggungjawabkan menurut lini usaha.

Penelitian yang dilakukan oleh Young et al. (2012) dalam penelitiannya yang mengkaji implikasi dari keuntungan dan kerugian nilai wajar kewajiban yang timbul dari penerapan Pernyataan Standar Akuntansi Keuangan No. 159 (FAS 159). Hasil dari penelitian ini diketahui bahwa terdapat hubungan positif antara return saham dan keuntungan/kerugian dari kewajiban keuangan. Hasil ini menunjukkan bahwa keuntungan dan kerugian dari kewajiban merupakan nilai yang relevan bagi investor dalam pengambilan keputusan investasi mereka. Penelitian yang dilakukan oleh Nurasiah (2014) yang meneliti tentang pengaruh dari keuntungan/kerugian perubahan nilai wajar dari kewajiban terhadap return saham dan risiko kredit perusahaan. Hasil penelitian ini dilihat dari analisis regresi linier berganda yang dilakukan di mana diperoleh hasil bahwa laba bersih setelah keuntungan/kerugian perubahan nilai wajar berpengaruh positif signifikan terhadap return saham perusahaan serta laba bersih dan laba setelah keuntungan/kerugian atas perubahan nilai wajar kewajiban secara bersamasama memiliki risiko yang relevan.

Tujuan penelitian ini adalah untuk menganalisis pengaruh keuntungan/kerugian perubahan nilai dari instrumen hutang, laba bersih setelah keuntungan kerugian perubahan nilai dari instrumen hutang dan laba per lembar saham perusahaan terhadap return saham dan pengaruh laba bersih setelah keuntungankerugian perubahan nilai dari instrumen hutang dan laba bersih tahun berjalan terhadap beta return. 


\section{TINAJUAN PUSTAKA DAN PENGEMBANGAN HIPOTESIS}

\section{Agency Theory}

Perubahan nilai wajar kewajiban perbankan, baik itu berupa keuntungan ataupun kerugian, cenderung akan mempengaruhi laba perusahaan. Peningkatan laba suatu perusahaan akan mendorong peningkatan harga saham sehingga return saham perusahaan juga akan meningkat dan risiko perusahaan akan semakin tinggi. Ketika risiko bank meningkat, maka cenderung akan terjadi asimetri informasi yang semakin besar antara investor dengan manajer.

Masalah asimetri informasi ini dibahas di dalam teori keagenan, dimana disebutkan dalam teori keagenan, agen biasanya dianggap sebagai pihak yang ingin memaksimumkan dirinya tetapi ia tetap selalu berusaha memenuhi kontrak. Hubungan keagenan, adalah hubungan antara prinsipal dan agen yang di dalamnya agen bertindak atas nama dan untuk kepentingan prinsipal dan atas tindakannya tersebut agen mendapatkan imbalan tertentu (Suwardjono, 2013:485)

Dalam suatu entitas, pada umumnya agen memiliki informasi yang lebih banyak dibandingkan dengan prinsipalnya sehingga menimbulkan adanya asimetri informasi. Informasi yang lebih banyak dimiliki oleh manajer dapat memicu melakukan tindakantindakan yang sesuai dengan keinginan untukmemaksimumkan kepentingannya. Sedangkan bagi pemilik modal dalam hal ini investor, akan sulit untuk mengontrol secara efektif tindakan yang dilakukan oleh manajemen karena hanya memiliki sedikit informasi yang ada. Oleh karena itu, terkadang kebijakan-kebijakan tertentu yang dilakukan oleh manajemen perusahaan tanpa sepengetahuan pihak pemilik modal atau investor.

\section{Teori Sinyal}

Return saham dan beta return perusahaan dapat memberikan sinyal baik (good news) atau sinyal buruk (bad news) perusahaan kepada para pengguna informasi keuangan perusahaan tersebut. Teori sinyal dapat menjelaskan bahwa pemberian sinyal pada informasi return saham dan risiko perusahaan dapat mempengaruhi investor dalam berinvestasi.Signaling theory (Leland dan Pyle dalam Scott, 2003:423) menyatakan bahwa pihak eksekutif perusahaan yang memiliki informasi lebih baik mengenai perusahaannya akan terdorong untuk menyampaikan informasi tersebut kepada calon investor dimana perusahaan dapat meningkatkan nilai perusahaan melalui pelaporannya dengan mengirimkan sinyal melalui laporan tahunannya.

Return saham diharapkan mampu dijadikan sinyal oleh perusahaan dalam menarik minat investor untuk berinvestasi pada perusahaan tersebut. Investor akan bereaksi positif apabila melihat tingginya nilai return saham perusahaan tersebut dan cenderung tertarik untuk berinvestasi pada perusahaan tersebut.

\section{Akuntansi Nilai Wajar}

Nurasiah (2014) menyebutkan akuntansi nilai wajar telah dianjurkan oleh International Accounting Standards Board (IASB) dan pembuat standar akuntansi lainnya, dan secara luas telah diterapkan untuk mengukur aset dan kewajiban keuangan selama beberapa dekade. Pernyataan Standar Akuntansi Keuangan (PSAK) No 50 tentang Instrumen Keuangan: Penyajian, menyebutkan Nilai wajar adalah jumlah suatu aset dipertukarkan, atau liabilitas diselesaikan, antara pihak-pihak yang berkeinginan dan memiliki pengetahuan memadai dalam suatu transaksi yang wajar. 
Serupa dengan yang diungkapkan dalam IFRS 13 tentang Fair Value Measurement yang mendefinisikan nilai wajar sebagai the price that would be received to sell an asset or paid to transfer a liability in an orderly transaction between market participants at the measurement date (ie an exit price) yaitu harga yang akan diterima untuk menjual aset atau dibayar untuk mentransfer kewajiban dalam transaksi teratur antara pelaku pasar pada tanggal pengukuran (yaitu harga exit). Ketika mengukur nilai wajar, entitas menggunakan asumsi bahwa pelaku pasar akan menggunakan ketika harga yang aktiva atau kewajiban dalam kondisi pasar saat ini, termasuk asumsi tentang risiko. Akibatnya, sebuah entitas bermaksud untuk memiliki aset atau untuk menyelesaikan atau memenuhi kewajiban tidak relevan ketika mengukur nilai wajar.

\section{Return Saham}

Sayidatina, (2011) mengungkapkan motivasi para investor melakukan investasi adalah harapan untuk memperoleh return yang sesuai. Tanpa adanya return, tentunya para investor tidak akan bersedia melakukan investasi. Jadi, dalam hal ini tujuan utama seseorang melakukan investasi adalah untuk memperoleh return baik secara langsung maupun tidak langsung.

Menurut Jogiyanto (2010:205) return merupakan hasil yang diperoleh dari investasi. Menurut Jogiyanto (2010:205) return dapat dibedakan menjadi 2 (dua), antara lain:

1. Return Realisasi

Return realisasi (realized return) merupakan return yang telah terjadi. Return realisasi dihitung berdasarkan data historis. Return realisasi penting karena digunakan sebagai salah satu pengukur kinerja dari perusahaan. Return histori ini juga berguna sebagai dasar penentu return ekspektasian (expected return) dan risiko dimasa datang.

2. Return Ekspektasian

Return ekspektasian (expected return) merupakan return yang diharapkan akan diperoleh oleh investor di masa mendatang. Berbeda dengan return realisasi yang sifatnya sudah terjadi, return ekspektasi sifatnya belum terjadi.

\section{Beta Return}

Investor selalu menghadapi dua masalah didalam berinvestasi yaitu return dan risiko mempunyai dua komponen yang tidak dapat dihindari dari investasi. Return dan risiko mempunyai hubungan yang positif (Jogiyanto, 2010:227). Semakin tinggi risiko, maka semakin tinggi pula expected returnnya, begitu pula sebaliknya, semakin rendah risiko semakin rendah pula expected returnnya. Menurut Jogiyanto (2010:375) beta merupakan suatu pengukur volatilitas (volatility) return suatu sekuritas atau return portofolio terhadap return pasar.

\section{Laba Bersih}

Laba adalah tambahan kemampuan ekonomik yang ditandai dengan kenaikan capital dalam suatu periode yang berasal dari kegiatan produktif dalam arti luas yang dapat dikonsumsi atau ditarik oleh emtitas penguasa/pemilik capital tanpa mengurangi kemampuan ekonomik kapital mula-mula (awal perioda). (Suwardjono, 2013:509). Seperti dikutip dalam Suwardjono (2013:463) FASB menetapkan laba (disebut laba komprehensif) dalam SFAC No. 6, prg.70sebagai elemen statemen keuangan dan mendefinisinya sebagai perubahan ekuitas perusahaan selama periode tertentu dari transaksi dan peristiwa serta keadaan lainnya dari sumber lain selain pemilik. Mencakup 
semua perubahan ekuitas selama periode tertentu kecuali yang dihasilkan dari investasi oleh pemilik dan pembagian ke pemilik.

\section{Laba per Lembar Saham Perusahaan (earnings per share)}

EPS merupakan salah satu rasio keuangan yang sering digunakan oleh investor untuk menganalisa kemampuan perusahaan menghasilkan laba berdasarkan saham yang dimiliki. Hal ini menyebabkan EPS menjadi komponen penting yang harus diperhatikan dalam analisa perusahaan, karena informasi EPS suatu perusahaan menunjukkan besarnya laba bersih perusahaan yang siap dibagikan kepada semua pemegang saham dengan kata lain menggambarkan prospek earning perusahaan di masa mendatang. Besarnya EPS ini dapat diketahui dari informasi laporan keuangan perusahaan.

\section{Pengaruh Keuntungan dan Kerugian atas Perubahan Nilai dari Instrumen Hutang Terhadap Return Saham}

Agar bermanfaat, informasi harus relevan untuk memenuhi kebutuhan pemakai dalam proses pengambilan keputusan. Informasi memiliki kualitas relevan kalau dapat mempengaruhi keputusan ekonomi pemakai dengan membantu mereka mengevaluasi peristiwa masa lalu, masa kini atau masa depan, menegaskan, atau mengkoreksi, hasil evaluasi mereka di masa lalu (PSAK, 2012)

Studi industri perbankan secara konsisten menunjukkan relevansi nilai dari nilai wajar aset dan, kewajiban deposito jangka panjang nilai wajar utang (Barth et al, 2008). Keuntungan dan kerugian dari kewajiban merupakan nilai yang relevan bagi investor dan dapat diandalkan dalam pengambilan keputusan investasinya. Investor juga melihat perubahan nilai wajar sebagai lebih relevan ketika perusahaan mengantisipasi menjual atau menetap instrumen keuangan mereka dalam jangka pendek dibandingkan dengan yang dimiliki hingga jatuh tempo instrumen keuangan. (Young et al, 2012)

Penelitian yang dilakukan oleh Nurasiah (2014) menemukan bahwa keuntungan/kerugian perubahan nilai wajar kewajiban, baik untuk instrumen utang maupun instrumen utang lainnya, berpengaruh negatif signifikan terhadap return perusahaan. Perusahaan yang mencatat dan mengakui keuntungan atau kerugian perubahan nilai wajar kewajiban cenderung memiliki return saham yang lebih rendah.

Berdasarkan penjelasan dari penelitian terdahulu di atas, maka hipotesis yang diajukan adalah sebagai berikut:

$\mathbf{H}_{1}$ : Keuntungan dan kerugian atas perubahan nilai dari instrumen hutang berpengaruh positif terhadap returnsaham

\section{Pengaruh Earnings Per Share (EPS) Terhadap ReturnSaham}

EPS merupakan komponen penting yang harus diperhatikan dalam analisa perusahaan karena informasi EPS suatu perusahaan menunjukkan besarnya laba bersih perusahaan yang siap dibagikan kepada semua pemegang saham dengan kata lain menggambarkan prospek earning perusahaan di masa mendatang (Susilowati, 2011).

Hasil penelitian Susilowati (2011) menemukan bahwa bahwa laba per lembar saham secara parsial tidak berpengaruh terhadap return saham. Hasil ini serupa dengan hasil penelitian Nurasiah (2011) yang menemukan bahwa laba per lembar saham (EPS) tidak terbukti berpengaruh terhadap return saham. Namun, menurut penelitian yang dilakukan Barth (2008) menunjukkan bahwa adanya korelasi positif antara EPS dan return saham. Selain itu, penelitian yang dilakukan oleh Solechan (2009) juga menyatakan adanya pengaruh yang positif antara EPS dan return saham. 
Berdasarkan penjelasan dari penelitian terdahulu di atas, maka hipotesis yang diajukan adalah sebagai berikut:

$\mathbf{H}_{2} \quad$ : Earning Per Share (EPS) berpengaruh positif terhadap returnsaham

\section{Pengaruh Laba Bersih Setelah Dikurangi Keuntungan/Kerugian Perubahan Nilai dari Instrumen Hutang Terhadap Return Saham}

Sebuah perusahaan dapat memberikan pertimbangan bagi investor untuk berinvestasi dengan informasi-informasi yang diterbitkan perusahaan melalui laporan tahunan perusahaan tersebut. Salah satu informasi yang menjadi prioritas utama bagi investor untuk mengambil keputusan investasi adalah informasi laba.

Saputra (2011) dalam penelitiannya menemukan bahwa variabel laba akuntansi memiliki pengaruh yang positif dan signifikan pada return saham. Ini menyimpulkan bahwa semakin besar laba akuntansi, maka tingkat return saham perusahaan akan semakin tinggi.

Nurasiah (2014) dalam penelitiannya menemukan bahwalaba bersih setelah keuntungan/kerugian perubahan nilai wajar berpengaruh positif signifikan terhadap return saham perusahaan. Hasil ini menunjukkan bahwa informasi keuntungan dan kerugian dari perubahan nilai wajar kewajiban memiliki nilai yang relevan bagi investor dalam pengambilan keputusan investasinya.

Berdasarkan penjelasan dari penelitian terdahulu di atas, maka hipotesis yang diajukan adalah sebagai berikut:

$\mathbf{H}_{3}$ : Laba bersih setelah dikurangi keuntungan/kerugian perubahan nilai dari instrumen hutang berpengaruh positif terhadap returnsaham

\section{Pengaruh Laba Bersih Setelah Dikurangi Keuntungan/Kerugian Perubahan Nilai dari Instrumen Hutang Terhadap Beta Return}

Risiko bank atas keuntungan dan kerugian dari penerapan nilai wajar mencerminkan kinerja fundamental suatu bank, hal ini memungkinkan pasar menyiimpulkan tentang daya saing mereka dan relevansi nilai dari keuntungan/kerugian nilai wajar harus meningkat (Lim et al, 2011).

Nurasiah (2014) dalam penelitiannya menemukan bahwa laba bersih setelah dikurangi keuntungan/kerugian perubahan nilai wajar kewajiban berpengaruh negative dan tidak signifikan terhadap beta return saham. Akuntansi nilai wajar untuk kewajiban dapat mengurangi volatilitas laba perusahaan sehingga lebih informatif dalam menilai risiko ekonomi perusahaan. Hasil penelitian tersebut konsisten pula dengan hasil penelitian yang dilakukan oleh Young et al. (2012) yang menyimpulkan bahwa pengukuran nilai wajar merupakan risiko yang relevan bagi investor dalam menilai volatilitas ekonomi perusahaan.

$\mathbf{H}_{4}$ : Laba bersih setelah dikurangi keuntungan/kerugian perubahan nilai dari instrumen hutang berpengaruh positif terhadap beta return

\section{Pengaruh Laba Bersih Tahun Berjalan Bersih Terhadap Beta Return}

Yulianto (2010) berpendapat bahwa peningkatan laba akan mendorong peningkatan harga saham sehingga akan memperkecil resiko. Ketika bank menjadi lebih berisiko, maka akan terjadi asimetri informasi yang lebih besar antara investor dan manajer. Akuntansi nilai wajar menjadi penting dalam memberikan informasi tambahan 
ke pasar untuk menilai arus kas masa depan dan daya saing kegiatan bank yang berisiko (Nurasiah, 2014).

Nurasiah (2014) dalam penelitiannya menemukan bahwa standar laba bersih berpengaruh signifikan terhadap beta return saham. Hasil ini menunjukkan bahwa laba bersih memiliki risiko yang relevan terhadap beta return saham. Berdasarkan penjelasan dari penelitian terdahulu di atas, maka hipotesis yang diajukan adalah sebagai berikut:

H5 : Laba bersih tahun berjalan berpengaruh positif terhadap beta return

\section{Populasi dan Sampel}

\section{METODE PENELITIAN}

Populasi dalam penelitian ini adalah seluruh perusahaan perbankan yang terdaftar di Bursa Efek Indonesia (BEI) selama periode tahun 2010-2013. Dari populasi ini, dipilih populasi sasaran yang semuanya menjadi sampel penelitian. Populasi sasaran pada penelitian ini adalah bank umum devisa yang terdaftar di Bursa Efek Indonesia tahun 2010 - 2013 dan diperoleh 23 perusahaan sehingga untuk periode 3 tahun pengamatan menjadi 108 sampel.

\section{Variabel dan Pengukuran}

\section{Return saham}

Returnsaham digunakan untuk menangkap respon pasar atas pelaporan keuntungan/kerugian dari perubahan nilai wajar kewajiban. Return merupakan imbalan yang diharapkan investor akan diperoleh atas investasi yang dilakukan di suatu perusahaan (Sayidatina, 2011). Relevansi nilai merupakan pelaporan angkaangka akuntansi yang memiliki suatu nilai prediksi berkaitan dengan nilai-nilai pasar ekuitas yang mencerminkan respon investor terhadap informasi akuntansi. (Nurasiah, 2014). Mengacu pada penelitian yang dilakukan oleh Nurasiah (2014) stock return dihitung 5 (lima) hari trading setelah publikasi laporan keuangan perusahaan. Return saham dalam penelitian ini dihitung dengan menggunakan rumus sebagai berikut (Jogiyanto, 2010:206):

Keterangan:

$$
\text { Return saham }=\frac{\mathrm{p}_{\mathrm{t}}-\mathrm{p}_{\mathrm{t}-1}}{\mathrm{P}_{\mathrm{t}-1}}
$$

$\mathrm{P}_{\mathrm{t}} \quad$ : Harga penutupan (closing price) saham i pada periode $\mathrm{t}$

$\mathrm{P}_{\mathrm{t}-1}$ : Harga penutupan (closing price) saham i pada periode sebelumnya.

\section{Beta Return}

Beta merupakan pengukur risiko sistematik suatu sekuritas atau portfolio relatif terhadap risiko pasar. Semakin tinggi risiko pasar semakin tinggi tingkat keuntungan yang diharapkan dari suatu sekuritas atau portofolio (Weston dan Copeland, 2010) dalam (Nurasiah, 2014). Pengukuran yang digunakan dalam penelitian ini menggunakan market beta model. Pengukuran ini mengacu pada penelitian yang dilakukan Young et.al.(2012) dan Nurasiah (2014). Rumus dari pengukuran tersebut adalah sebagai berikut:

$$
B E T A=\frac{\left(n \Sigma R E T_{m} * R E T_{i}-\Sigma R E T_{m} \Sigma R E T_{i}\right)}{\left(n \Sigma R E T_{m}^{2}-\left(\Sigma R E T_{m}\right)^{2}\right)}
$$

Dimana: 
BETA : risiko pasar atas perubahan harga saham untuk perusahaan i pada tahun ke-t

$R E T_{m} \quad$ : return untuk saham perusahaan berdasarkan pasar untuk perusahaan i pada tahun ke-t yang dihitung dengan perubahaan dari indeks harga saham gabungan untuk perusahaan i untuk tahun $\mathrm{t}$

$R E T_{i} \quad$ : returnsaham perusahaan untuk perusahaan i pada tahun ke-t

\section{Laba Bersih Tahun Berjalan}

Laba bersih tahun berjalan adalah laba bersih yang dimiliki perusahaan pada tahun berjalan. Laba bersih merupakan salah satu faktor yang dapat menggambarkan kinerja perusahaan dan risiko untuk perusahaan dengan eksposur yang signifikan terhadap perubahan nilai wajar dari instrumen keuangan (Hodder et al, 2005).

\section{Keuntungan/Kerugian Perubahan Nilai dari Instrumen Hutang}

Keuntungan/kerugian perubahan nilai dari instrumen hutang, adalah perubahan nilai wajar dari instrumen hutang yang dicatat serta diakui sebagai keuntungan/kerugian nilai wajar dalam laporan laba rugi perusahaan perbankan. Item - item yang termasuk dalam istrumen hutang dalam industri perbankan ini adalah utang jangka pendek, utang jangka panjang, utang subordinasi (subordinated $d e b t$ ) dan utang wesel serta instrumen hutang lainnya yang terdiri dari simpanan berjangka (time deposit) nasabah, simpanan dari bank lain, dan pinjaman dana (fund borrowing), serta liabilitas lainnya. Mengacu pada penelitian yang dilakukan Nurasiah (2014), keuntungan/kerugian perubahan nilai dari instrumen hutang dihitung dengan cara sebagai berikut:

$$
\text { Hutang }_{t}-\text { Hutang }_{t-1}
$$

\section{Laba Bersih Setelah Keuntungan/ Kerugian Perubahan Nilai dari Instrumen Hutang}

Laba bersih setelah keuntungan/kerugian perubahan nilai dari instrument hutang adalah laba bersih perusahaan pada tahun berjalan setelah dikurangi keuntungan/kerugian perubahan nilai wajar yang belum direalisasi (Nurasiah, 2014).

\section{Laba per Lembar Saham Perusahaan}

Laba per lembar saham perusahaan atau earnings per share (EPS) adalah laba setelah beban bunga. (Barth, 2008). Mengacu pada penelitian Nurasiah (2014) laba per lembar saham perusahaan dimasukkan sebagai variabel sebagai proksi untuk perubahan nilai aset berkaitan dengan ekuitas. Earning per share dapat dirumuskan sebagai berikut:

$$
\text { EPS }=\frac{\text { Laba Bersih }}{\text { Jumlah Saham Beredar }}
$$

\section{Analisis Data}

Untuk menguji hubungan antara variabel dependen dan variabel independen pada penelitian ini digunakan analisis deskriptif dan uji statistik. Alat pengolah data yang digunakan dalam penelitian ini adalah SPSS. Pengujian hipotesis dalam penelitian ini menggunakan analisis regresi berganda Untuk mengujireturn saham, digunakan analisis regresi linier berganda dengan rumus: 


$$
R E T=\alpha_{0}+\alpha_{1} N I_{\Delta L I A B_{i t}^{i t}}+\alpha_{2} \Delta \text { Debt }_{\text {Instit }_{i t}}+\alpha_{3} \text { EPS }+\varepsilon_{i_{t}}
$$

Keterangan:

\begin{tabular}{|c|c|}
\hline$\alpha_{0}$ & : Konstanta \\
\hline$\alpha_{1}-\alpha_{3}$ & : Koefisien Variabel \\
\hline$R E T$ & $\begin{array}{l}\text { Return saham lima hari trading setelah publikasi laporan keuangan } \\
\text { perusahaan pada tahun } \mathrm{t}\end{array}$ \\
\hline$N I_{\triangle L I A B_{i t}}$ & : Laba bersih dikurangi keuntungan/ kerugian perubahan nilai wajar \\
\hline & $\begin{array}{l}\text { kewajiban perusahaan i pada tahun ke } \mathrm{t} \text {, diskala dengan total asset } \\
\text { tahun berjalan }\end{array}$ \\
\hline$\Delta$ Debt $_{\text {Inst }}{ }_{\text {it }}$ & $\begin{array}{l}\text { Keuntungan/kerugian dari perubahan nilai wajar instrumen hutang } \\
\text { perusahaan i pada tahun ke } t \text {, diskala dengan total asset tahun berjalan }\end{array}$ \\
\hline 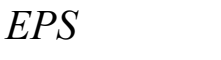 & Laba perlembar saham perusahaan i pada tahun ket \\
\hline & Kesalahan pengganggu \\
\hline
\end{tabular}

Untuk menguji beta return mengenai risiko, digunakan model adjusted market beta dengan rumus:

$$
\operatorname{BETA}_{i_{\mathrm{t}}}=\beta_{0}+\beta_{1}\left(N I_{i_{\mathrm{t}}}\right)+\beta_{2}\left(N I_{\Delta L I A B_{i \mathrm{it}}}\right)+\varepsilon_{i_{\mathrm{t}}}
$$

Keterangan:

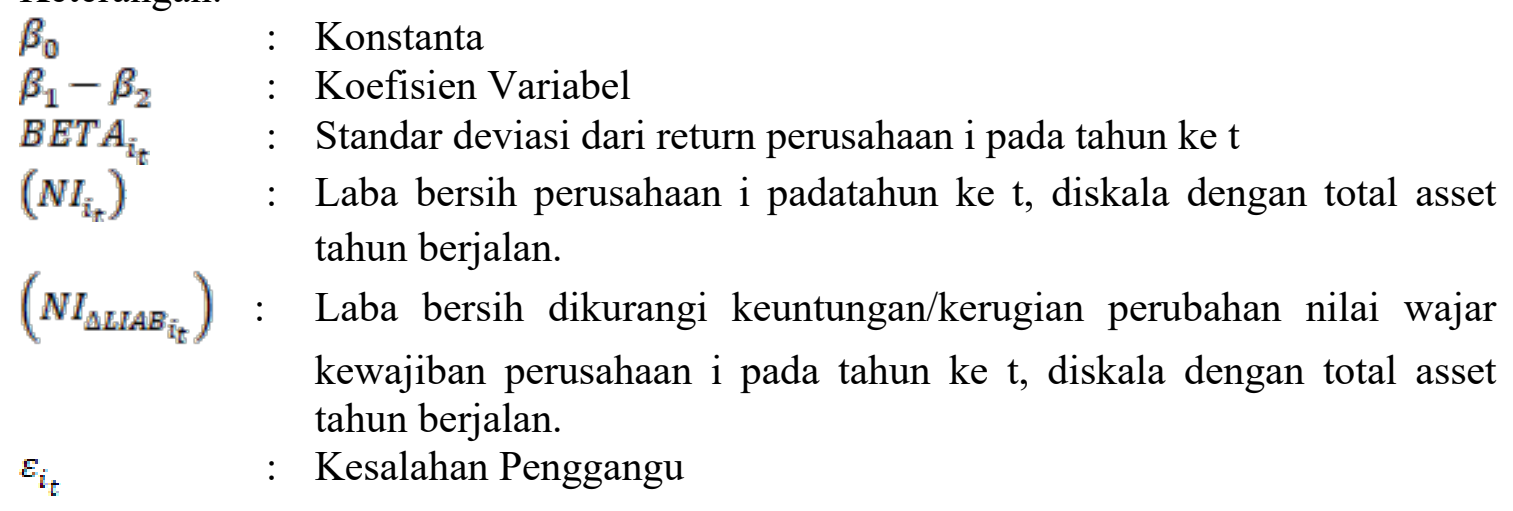

\section{HASIL DAN PEMBAHASAN}

\section{Statistik Deskriptif}

Berdasarkan tabel 1, statistik deskriptif dapat dijelaskan sebagai berikut; Nilai rata-rata return saham perusahaan bank umum devisa dari tahun 2010-2013 adalah sebesar 1281,078. Nilai return saham tertinggi adalah 4599, Sedangkan nilai return saham terkecil yaitu sebesar 123.90. Standar deviasi sebesar 912.6858 lebih kecil dari nilai rata-rata yang artinya bahwa data mempunyai sebaran yang kecil sehingga data return saham yang digunakan merupakan data yang baik. Nilai rata-rata beta return perusahaan bank umum devisa dari tahun 2010-2013 adalah sebesar 0,806. Nilai beta return tertinggi adalah 2,766. Sedangkan nilai beta return terkecil yaitu sebesar -1.861. Standar deviasi sebesar 0,8512 sedikit lebih tinggi dari nilai rata-rata yang artinya bahwa data mempunyai sebaran yang tidak terlalu kecil.

Nilai rata-rata untuk variabel instrumen keuntungan/kerugian hutang perusahaan bank umum devisa dari tahun 2010-2013 adalah sebesar 0,148. Nilai variabel instrumen keuntungan/kerugian hutang tertinggi adalah 1.159. Sedangkan nilai variabel instrumen keuntungan/kerugian hutang terkecil yaitu sebesar 0,176. Standar deviasi sebesar 
0,1451 lebih kecil dari nilai rata-rata yang artinya bahwa data mempunyai sebaran yang kecil sehingga data variabel instrumen keuntungan/kerugian hutang yang digunakan merupakan data yang baik. Nilai rata-rata laba per lembar saham perusahaan sampel adalah sebesar 92.153. Nilai laba per lembar saham tertinggi adalah 373.99. Sedangkan nilai laba per lembar saham terkecil yaitu sebesar 4.10. Standar deviasi sebesar 64.5886 lebih kecil dari nilai rata-rata yang artinya bahwa data mempunyai sebaran yang kecil sehingga data laba per lembar saham yang digunakan merupakan data yang baik.

Nilai rata-rata laba bersih perusahaan bank umum devisa dari tahun 2010-2013 adalah sebesar 0,014 Nilai laba bersih tertinggi adalah 0,0340. Sedangkan nilai laba bersih terkecil yaitu sebesar -0,006. Standar deviasi sebesar 0,0083 lebih kecil dari nilai rata-rata yang artinya bahwa data mempunyai sebaran yang kecil sehingga data laba bersih yang digunakan merupakan data yang baik. Nilai rata-rata variabel laba bersih setelah keuntungan/kerugian hutang perusahaan bank umum devisa dari tahun 20102013 adalah sebesar -0,118. Nilai variabel laba bersih setelah keuntungan/kerugian hutang tertinggi adalah 0,176, Sedangkan nilai variabel laba bersih setelah keuntungan/kerugian hutang terkecil yaitu sebesar -0,328. Standar deviasi sebesar 0,088 lebih besar dari nilai rata-rata yang artinya bahwa data mempunyai sebaran yang cukup luas namun data variabel laba bersih setelah keuntungan/kerugian hutang yang digunakan masih dapat dikatakan cukup baik karna nilai tersebut tidak terlalu jauh dengan nilai rata-ratanya.

\section{Uji Asumsi Klasik}

Uji asumsi klasik yang digunakan dalam penelitian ini meliputi uji normalitas, uji multikolonieritas, uji heteroskedastisitas, dan uji autokorelasi. hasil uji asumsi klasik dapat dilihat pada tabel 2. Pada tabel 2, dapat dilihat bahwa semua model regresi telah memenuhi asumsi klasik sehingga layak untuk diuji dalam persamaan regresi. Semua model memiliki tingkat signifikansi besar dari 0,05 yang berarti bahwa data dalam penelitian ini terdistribusi normal. Nilai tolerance $>0,10$ dan VIF $<10$ sehingga dapat disimpulkan bahwa variabel bebas tidak saling berkorelasi secara signifikan (bebas multikolonieritas). Tingkat signifikansi pada uji heteroskedastisitas semua variabel di atas 5\% atau 0,05, sehingga model regresi tersebut terbebas dari asumsi heteroskedastisitas. Nilai D-W yang diperoleh untuk semua persaman terletak diantara du dan 4-du yang merupakan daerah bebas autokorelasi.

\section{Hasil Analisis Regresi}

\section{Hasil Analisis Regresi Linier Berganda Model Regresi 1}

Analisis regresi linier berganda dimaksudkan untuk menguji sejauh mana pengaruh variabel-variabel independen terhadap variabel dependen. Variabel independen dalam penelitian ini adalah EPS (X1), instrumen keuntungan /kerugian hutang (X2), laba bersih setelah keuntungan/kerugian (X3). Sedangkan variabel dependennya adalah return saham (Y). Hasil pengujian menunjukkan bahwa variabel laba bersih setelah dikurangi keuntungan/ kerugian perubahan nilai dari instrumen hutang, instrumen keuntungan dan kerugian atas perubahan nilai dari instrumen hutang, dan EPSberpengaruh secara simultan terhadap return saham dengan tingkat signifikansi sebesar 0.000ataulebih kecil dari 0.05.

Secara parsial, ditemukan bahwainstrumen keuntungan /kerugian hutang berpengaruh negatif namun tidak signifikan sehingga perumusan hipotesis pertama (H1) yang menyatakan bahwa keuntungan dan kerugian atas perubahan nilai dari 
instrumen hutang berpengaruh positif terhadap return saham tidak dapat diterima (ditolak).

Hasil tersebut konsisten degan hasil penelitian yang dilakukan Nurasiah (2014) yang menunjukkan adanya hubungan negatif antara return saham dan keuntungan/kerugian perubahan nilai wajar kewajiban dan penelitian yang dilakukan oleh Barth et al, (2008) yang menunjukkan adanya hubungan negatif antara stock returndengan perubahan risiko kredit perusahaan. Namun, hasil penelitian ini bertolak belakang dengan penelitian yang dilakukan Young et al, (2012) yang menyatakan adanya hubungan positif antara instrumen utang dengan stock return.

Untuk variabelpengaruh Earning Per Share (EPS) terhadap return sahamditemukan bahwa variabel laba per lembar saham (EPS) berpengaruh positif dan signifikan terhadap return saham sehingga perumusan hipotesis kedua (H2) yang menyatakan bahwa earning per share (EPS) berpengaruh positif terhadap return saham dapat diterima. Hasil ini sesuai dengan teori yang berkembang yang menyatakan bahwa semakin tinggi laba per lembar saham (EPS) maka akan semakin tinggi keuntungan atas penjualan saham (return saham) perusahan.

Hasil tersebut konsisten degan hasil penelitian yang dilakukan oleh Barth et al, (2008) yang menunjukkan bahwa adanya korelasi positif antara laba per lembar saham (EPS) dan return saham dan penelitian yang dilakukan oleh Solechan (2009) yang menunjukkan adanya pengaruh yang positif antara EPS terhadap return saham perusahaan. Namun, hasil penelitian ini bertolak belakang dengan penelitian yang dilakukan oleh Nurasiah (2014) yang menyatakan bahwa hasil pengujian laba per lembar saham (EPS) tidak terbukti berpengaruh terhadap return saham

Pada variabel pengaruh laba bersih setelah dikurangi keuntungan/ kerugian perubahan nilai dari instrumen hutang terhadap return saham, hasil penelitian menemukan bahwa laba bersih setelah keuntungan/kerugian berpengaruh negatif namun tidak signifikan. Hal ini berarti bahwa laba bersih setelah dikurangi keuntungan/kerugian perubahan nilai dari instrumen hutang dapat menurunkan return saham perusahaan. Hal ini disebabkan karena menurunnya volatilitas laba perusahaan sehingga efek tidak langsungnya adalah dengan menurunnya nilai return saham perusahaan tersebut. Hal ini menyebabkan perumusan hipotesis ketiga (H3) yang menyatakan bahwa laba bersih setelah dikurangi keuntungan/kerugian perubahan nilai dari instrumen hutang berpengaruh positif terhadap return saham tidak dapat diterima (ditolak).

Namun, hasil penelitian ini bertolak belakang dengan penelitian yang dilakukan oleh Nurasiah (2014) yang menyatakan bahwa menemukan bahwalaba bersih setelah keuntungan/kerugian perubahan nilai wajar berpengaruh positif signifikan terhadap return saham perusahaan dan hasil penelitian Young et al, (2012) yang menyimpulkan bahwa perusahaan yang menerapkan FAS 159: Fair Value Gains and Losses cenderung memberikan sinyal positif bagi investor dalam mengestimasi volatilitas laba perusahaan.

\section{Hasil Analisis Regresi Linier Berganda Model Regresi 2}

Analisis regresi linier berganda untuk model regresi 2 terdiri dari dua variabel independen dan satu variabel dependen. Variabel independen dalam model regresi 2 adalah laba bersih setelah keuntungan/kerugian (X1), dan laba bersih(X2). Sedangkan variabel dependennya adalah beta return (Y).Hasil pengujian menunjukkan bahwa variabel laba bersih setelah dikurangi keuntungan/ kerugian 
perubahan nilai dari instrumen hutang dan laba bersih tahun berjalan tidak berpengaruh secara simultan terhadap beta return dengan tingkat signifikansi sebesar 0.064atausedikit lebih besar dari 0.05 hasil ini menunjukkan bahwa laba bersih tahun berjalan dan laba setelah keuntungan/kerugian atas perubahan nilai wajar kewajiban secara bersama-sama tidak berpengaruh terhadap beta return perusahaan.

Secara parsial, untuk variabelpengaruh laba bersih setelah dikurangi keuntungan/ kerugian perubahan nilai dari instrumen hutang terhadap beta returnditemukan bahwa laba bersih setelah keuntungan/kerugian berpengaruh negatif namun tidak signifikan sehingga perumusan hipotesis keempat (H4) yang menyatakan bahwa laba bersih setelah dikurangi keuntungan/kerugian perubahan nilai dari instrumen hutang berpengaruh positif terhadapbeta returntidak dapat diterima (ditolak).Hal ini mengindikasikan bahwa akuntansi nilai wajar untuk kewajiban dapat mengurangi volatilitas laba perusahaan namun lebih informatif dalam menilai risiko ekonomi perusahaan.

Hasil tersebut konsisten dengan hasil penelitian yang dilakukan oleh Young et al, (2012) yang menunjukkan bahwa pengukuran nilai wajar merupakan risiko yang relevan bagi investor dalam menilai volatilitas ekonomi perusahaan dan penelitian yang dilakukan oleh Nurasiah (2014) yang menyatakan tidak ada pengaruh laba bersih setelah dikurangi keuntungan/kerugian perubahan nilai wajar kewajiban terhadap beta return.

Secara parsial variabel pengaruh laba bersih tahun berjalan bersih terhadap beta return, ditemukan bahwa laba bersih tahun berjalan berpengaruh positif dan signifikan sehingga perumusan hipotesis kelima (H5) yang menyatakan bahwa laba bersih tahun berjalan berpengaruh positif terhadapbeta returndapat diterima.Hasil ini menunjukkan bahwa laba bersih tanpa memasukan keuntungan/kerugian perubahan nilai wajar kewajiban memiliki volatilitas yang lebih tinggi, namun informasi laba bersih tersebut kurang atau tidak memiliki nilai yang relevan bagi investor dalam menilai risiko ekonomi yang mendasari perusahaan.Hasil tersebut konsisten dengan hasil penelitian yang dilakukan oleh Nurasiah (2014) yang menunjukkan bahwa adanya korelasi signifikan antara laba bersih dan beta return perusahaan.

\section{SIMPULAN, IMPLIKASI, KETERBATASAN DAN SARAN}

\section{Simpulan}

Penelitian ini bertujuan untuk menguji pengaruh keuntungan /kerugian atas perubahan nilai dari instrumen hutang, EPS, danlaba bersih setelah dikurangi keuntungan/kerugianperubahan nilai dari instrumen hutang terhadap return saham serta pengaruh laba bersih dan laba bersih setelah dikurangi keuntungan/kerugianperubahan nilai dari instrumen hutang terhadap beta return. Hasil penelitian menemukan bahwa:

1. Keuntungan /kerugian atas perubahan nilai dari instrumen hutangtidak berpengaruh terhadap returnsaham perusahaan.

2. Variabel laba per lembar saham (EPS) berpengaruh positif dan signifikan terhadap return saham.

3. Penelitian ini juga menemukan laba bersih setelah dikurangi keuntungan/kerugianperubahan nilai dari instrumen hutang tidak berpengaruh terhadapreturn saham. 
4. Laba bersih setelah dikurangi keuntungan/kerugian perubahan nilai dari instrumen hutang tidak berpengaruh terhadapbeta return

5. Laba bersih tahun berjalan berpengaruh positif dan signifikan terhadap beta return.

\section{Keterbatasan dan Saran}

Adapun keterbatasan dan saran dari penelitian ini adalah sebagai berikut:

1. Penelitian ini hanya terbatas pada perusahaan bank umum devisa, untuk peneliti selanjutnya disarankan menggunakan bank umum secara keseluruhan atau sektor lainnya.

2. Penelitian ini tidak menguji secara bertingkat, sehingga alasan terjadinya keuntungan/kerugian perubahan nilai wajar yang timbul tidak dapat dideteksi dengan pasti.

3. Penelitian ini hanya terfokus untuk meneliti nilai wajar kewajiban terhadap return saham dan beta return, untuk peneliti selanjutnya disarankan untuk mengambil topik nilai wajar ekuitas ataupun penerapan nilai wajar untuk aset.

\section{DAFTAR PUSTAKA}

Barth, M.E., Beaver, W.H., Landsman W.R., 1996. "Value Relevance of Banks Fair Value Disclosure Under SFAS No. 107”. The Accounting Review Vol 71, 513-537.

Barth, M., L. D. Hodder, and S. R. Stubben. 2008. "Fair value accounting for liabilities and own credit risk." The Accounting Review 83: 629- 664.

Ghozali, Imam. 2005. Aplikasi Analisis Multivariate dengan Program SPSS. Semarang: Badan Penerbit Universitas Diponegoro.

Handoko. 2010. Nilai wajar (fair value). Rohgoyokwoksumo.wordpress.com. diakses pada februari 2015

Hardiani, Indri., 2014. "Fair Value Measurement: Masalah Baru atau Solusi pada Pelaporan Keuangan (Studi Fenomenologi atas Pandangan Auditor)". Skripsi. Fakultas Ekonomi. Universitas Diponegoro Semarang.

Hartono, Jogiyanto. 2010. Teori Portofolio dan Analisis Investasi. Yogyakarta: BPFE.

Hassan, M.S., Percy, Majella., and Stewart, Jenny., 2006. "The Value Relevance of Fair Value Disclosures in Australian Firms in The Extractive Industries". Asian Academy of Management Journal of Accounting and Finance. Vol. 2, No. 1, 41-61, 2006.

Hodder, L.D., Hopkins, P.E., Wahlen, J.M., 2005. "Risk-relevance of Fair Value Income Measures for Commercial Banks". The Accounting Review 81, 337-375.

Ikatan Akuntan Indonesia. 2012. Standar Akuntansi Keuangan. Jakarta: IAI.

International Financial Reporting Standard (IFRS), 2011. "Fair Value Measurement". International Accounting Standard Committee, United State of America.

Koonce, L., K. Nelson, and C. Shakespeare. 2011. "Judging the relevance of fair value for financial instrument." The Accounting Review 86: 2075-2098

Laux, C., Leuz, C,. 2009. "The crisis of fair value accounting: Making sense of the recent debate". Accounting, Organizations and society 34, 826-834.

Laghi E., Pucci S., and Tutino M., 2012. "Fair Value Hierarchy in Financial Instruments Disclosure. Is Transparency Well Assessed for Investors? Evidence from Banking Industry". Working Paper, Roma Tre University.

Lim, C. Yeong., Lee, E., Walker., 2011. "Bank risk and the value relevance of fair value gains/losses". Working Paper, Singapore Management University. 
Martani, Dwi. 2011,. Dampak Implementasi IFRS Bagi Perusahaan.,staff.blog.ui.ac.id., diakses pada maret 2015

Mulatsih, Listiana Sri., Ghozali Maskie, dan Harry Susanto. 2009. "Analisis Reaksi Pasar Modal terhadap Pengumuman Right Issue di Bursa Efek Jakarta”. Wacana, Vol.12 No.4, Hal. 646-661.Munawir, S., 2012. Analisa Laporan Keuangan. Yogyakarta: Liberty Yogyakarta.

Nurasiah., Nuryani, Nunung., 2014. "Relevansi Nilai Serta Implikasi Risiko Atas Keuntungan Dan Kerugian Perubahan Nilai Wajar Kewajiban Perbankan Indonesia". Simposium Nasional Akuntansi, Kwik Kian Gie School of Business.

Saputra, Kadek Adi., Astika, Ida Bagus Putra., 2013. "Pengaruh Informasi Laba Akuntansi Dan Informasi Corporate Social and Responsibility Pada Return Saham (Studi Pada Perusahaan Pertambangan di BEI)". ISSN: 2302-8556. E-Jurnal Akuntansi Universitas Udayana

Sayidatina, Kartika., 2011. "Pengaruh Corporate Social Responsibility Terhadap Stock Return (Studi Empiris Perusahaan yang Terdaftar di BEI Tahun 2008-2009)". Skripsi. Fakultas Ekonomi. Universitas Diponegoro Semarang.

Scott, William R,. 2003. Financial Accounting Theory, Third Edition. USA: Prentice-Hall.

Sekaran, Uma. 2007. Metodelogi Penelitian Untuk Bisnis. Jakarta: Salemba Empat

Solechan, Achmad., 2009. "Pengaruh Manajemen Laba Dan Earning Terhadap Return Saham (Studi Empiris Perusahaan yang Go Public di BEI Tahun 2003 - 2006)”. tesis. Fakultas Ekonomi. Universitas Diponegoro Semarang.

Sugiyono. 2014. Statistika untuk Penelitian. Bandung: Alfabeta.

Susilowati, Yeye., Turyanto, Tri., 2011. "3Reaksi Signal Rasio Profitabilitas Dan Rasio Solvabilitas Terhadap Return Saham Perusahaan” Dinamika Keuangan dan Perbankan. Program Studi Akuntansi Universitas Stikubank Semarang.

Suwardjono. 2013. Teori Akuntansi Perekayasaan Pelaporan Keuangan, Edisi Ketujuh. Yogyakarta: BPFE.

Tim Perumus Pedoman Akuntansi Perbankan Indonesia. 2008. Pedoman Akuntansi Perbankan Indonesia. Direktorat Penelitian dan Pengaturan Perbankan, Bank Indonesia.

Tjun, Lauw Tjun., Marpaung, Elyzabet Indrawati., Setiawan, Santy., 2012. "Pengaruh Kompetensi dan Independensi Auditor Terhadap Kualitas Audit" Jurnal Akuntansi.Fakultas Ekonomi. Universitas Kristen Maranatha.

Wulandari, Sry., Arfan, Muhammad., Shabri, Muhammad., 2013. "Pengaruh Profitabilitas, Operating Profit Margin (Opm), Dan Financial Leverage Terhadap Perataan Laba (Income Smoothing) Pada Perusahaan Blue Chips di Indonesia (Studi Empiris Pada Perusahaan Lq 45 Yang Terdaftar Di Bursa Efek Indonesia Tahun 2007-2011)”. Jurnal Akuntansi. Fakultas Ekonomi. Universitas Syiah Kuala Banda Aceh.

Young, Ow Kevin., Lobo, Gerald., Chung, S.G., 2012. "Assesing the valuation and risk implications of fair value accounting for liabilities: Evidence from FAS 159 reported Gains and Losses". Working Paper, Singapore Management University.

Yulianto, Yulius., 2010. "Analisis Pengaruh Asset Growth, Earning Per Share, Debt to Total Asset, Return on Investment, Dan Deviden Yield Terhadap Beta Saham (Studi Pada Perusahaan Perbankan Yang Tercatat Di BEI Periode 2005-2007). Skripsi. Fakultas Ekonomi. Universitas Diponegoro Semarang. 


\section{Lampiran 1}

Daftar Bank yang Menjadi Sampel

\begin{tabular}{|c|c|c|}
\hline No & Kode & Nama Perusahaan \\
\hline 1 & AGRO & PT Bank Rakyat Indonesia Agroniaga \\
\hline 2 & BABP & PT Bank ICB BumiPutera \\
\hline 3 & BAEK & PT Bank Ekonomi Raharja \\
\hline 4 & BBCA & PT. Bank Central Asia \\
\hline 5 & BBKP & PT Bank Bukopin \\
\hline 6 & BBNI & PT Bank Negara Indonesia Tbk \\
\hline 7 & BBRI & PT Bank Rakyat Indonesia Tbk \\
\hline 8 & BBTN & PT Bank Tabungan Negara \\
\hline 9 & $\mathrm{BCIC}$ & PT Bank Mutiara \\
\hline 10 & BDMN & PT Bank Danamon \\
\hline 11 & BKSW & PT Bank QNB Kesawan \\
\hline 12 & BMRI & PT Bank Mandiri (Persero) Tbk \\
\hline 13 & BNGA & PT Bank CIMB Niaga \\
\hline 14 & BNII & PT Bank Internasional Indonesia \\
\hline 15 & BNLI & PT Bank Permata \\
\hline 16 & BSIM & PT Bank Sinar Mas \\
\hline 17 & BSWD & PT Bank of India Indonesia \\
\hline 18 & INPC & PT Bank Artha Graha Internasional Tbk \\
\hline 19 & MAYA & PT Bank Mayapada Internasional Tbk \\
\hline 20 & MEGA & PT Bank Mega Tbk \\
\hline 21 & NISP & PT. Bank OCBC NISP Tbk \\
\hline 22 & PNBN & PT Bank Panin Indonesia \\
\hline 23 & SDRA & PT Bank Himpunan Saudara 1906 Tbk \\
\hline
\end{tabular}

Sumber: www.idx.com (data diolah)

Lampiran 2 (Statistik Deskriptif)

Descriptive Statistics

\begin{tabular}{|c|r|r|r|r|r|}
\hline & $\mathrm{N}$ & \multicolumn{1}{|c|}{ Minimum } & Maximum & \multicolumn{1}{c|}{ Mean } & Std. Deviation \\
\hline RET & 92 & 123.90 & 4599.00 & 1281.0784 & 912.68583 \\
$\mathrm{BET}$ & 92 & -1.8618722 & 2.7666763 & .806547896 & .8511816748 \\
$\mathrm{DEBT}$ & 92 & -.1767763 & 1.1595410 & .148033282 & .1451508989 \\
$\mathrm{EPS}$ & 92 & 4.1000 & 373.9900 & 92.153561 & 64.5886153 \\
LABA & 92 & -.00635117 & .03408589 & .0147824939 & .00831891238 \\
NILIAB & 92 & -.3284385 & .1767607 & -.118670307 & .0880763978 \\
Valid N & 92 & & & & \\
(listwise) & 92 & & & & \\
\hline
\end{tabular}

28 | Relevansi Nilai Serta Implikasi Risiko Atas Keuntungan... 


\section{Lampiran 3. (Pengujian Hipotesis)}

\section{Uji Hipotesis Model Regresi 1}

\begin{tabular}{|c|c|r|r|r|r|}
\hline \multicolumn{7}{|c|}{ Model Summary } \\
\hline Model & \multicolumn{1}{|c|}{$\mathrm{R}$} & R Square & $\begin{array}{c}\text { Adjusted R } \\
\text { Square }\end{array}$ & $\begin{array}{c}\text { Std. Error of } \\
\text { the Estimate }\end{array}$ & $\begin{array}{c}\text { Durbin- } \\
\text { Watson }\end{array}$ \\
\hline 1 & $.521^{\mathrm{a}}$ & .272 & .247 & 792.04165 & 1815 \\
\hline
\end{tabular}

a. Predictors: (Constant), NILIAB, EPS, DEBT

b. Dependent Variable: RET

\begin{tabular}{|c|c|c|c|c|c|c|}
\hline \multicolumn{7}{|c|}{ ANOVA $^{b}$} \\
\hline & Model & Sum of Squares & Df & Mean Square & $\mathrm{F}$ & Sig. \\
\hline 1 & Regression & 20597545.943 & 3 & 6865848.648 & 10.945 & $.000^{\mathrm{a}}$ \\
\hline & Residual & 55205038.197 & 88 & 627329.980 & & \\
\hline & Total & 75802584.140 & 91 & & & \\
\hline
\end{tabular}

a. Predictors: (Constant), NILIAB, EPS, DEBT

b. Dependent Variable: RET

Coefficients $^{\mathbf{a}}$

\begin{tabular}{|c|c|c|c|c|c|c|c|}
\hline \multirow[b]{2}{*}{ Model } & \multicolumn{2}{|c|}{$\begin{array}{c}\text { Unstandardized } \\
\text { Coefficients }\end{array}$} & \multirow{2}{*}{\begin{tabular}{|c|}
$\begin{array}{c}\text { Standardized } \\
\text { Coefficients }\end{array}$ \\
Beta \\
\end{tabular}} & \multirow[b]{2}{*}{$\mathrm{T}$} & \multirow[b]{2}{*}{ Sig. } & \multicolumn{2}{|c|}{$\begin{array}{c}\text { Collinearity } \\
\text { Statistics }\end{array}$} \\
\hline & B & Std. Error & & & & Tolerance & VIF \\
\hline 1 (Constant) & 693.007 & 185.140 & & 3.743 & .000 & & \\
\hline EPS & 7.294 & 1.287 & .516 & 5.669 & .000 & .998 & 1.002 \\
\hline DEBT & -273.361 & 723.218 & -.043 & -.378 & .706 & .626 & 1.599 \\
\hline NILIAB & 367.689 & 1192.094 & .035 & .308 & .758 & .625 & 1.599 \\
\hline
\end{tabular}

a. Dependent Variable: RET

\section{Uji Hipotesis Model Regresi 2}

\begin{tabular}{|c|c|r|r|r|r|}
\hline \multicolumn{7}{|c|}{ Model Summary } \\
Model & $\mathrm{R}$ & R Square & $\begin{array}{c}\text { Adjusted R } \\
\text { Square }\end{array}$ & $\begin{array}{c}\text { Std. Error of } \\
\text { the Estimate }\end{array}$ & $\begin{array}{c}\text { Durbin- } \\
\text { Watson }\end{array}$ \\
\hline 1 & $.244^{\mathrm{a}}$ & .060 & .039 & .8345713710 & 2.152 \\
\hline
\end{tabular}

a. Predictors: (Constant), LABA, NILIAB

b. Dependent Variable: BET 
ANOVA ${ }^{b}$

\begin{tabular}{|rc|r|r|r|c|c|}
\hline \multicolumn{1}{|c|}{ Model } & Sum of Squares & df & Mean Square & F & Sig. \\
\hline 1 & Regression & 3.941 & 2 & 1.971 & 2.829 & $.064^{\mathrm{a}}$ \\
& Residual & 61.989 & 89 & .697 & & \\
& Total & 65.930 & 91 & & & \\
\hline
\end{tabular}

a. Predictors: (Constant), LABA, NILIAB

b. Dependent Variable: BET

\section{Coefficients $^{\mathrm{a}}$}

\begin{tabular}{|c|c|c|c|c|c|c|c|}
\hline \multirow[b]{2}{*}{ Model } & \multicolumn{2}{|c|}{$\begin{array}{c}\text { Unstandardized } \\
\text { Coefficients }\end{array}$} & \multirow{2}{*}{$\begin{array}{c}\begin{array}{c}\text { Standardized } \\
\text { Coefficients }\end{array} \\
\text { Beta }\end{array}$} & \multirow[b]{2}{*}{$\mathrm{T}$} & \multirow[b]{2}{*}{ Sig. } & \multicolumn{2}{|c|}{$\begin{array}{c}\text { Collinearity } \\
\text { Statistics }\end{array}$} \\
\hline & B & Std. Error & & & & Tolerance & VIF \\
\hline 1 (Constant) & .425 & .216 & & 1.968 & .052 & & \\
\hline NILIAB & -.102 & .994 & -.011 & -.103 & .918 & .999 & 1.001 \\
\hline LABA & 25.019 & 10.520 & .245 & 2.378 & .020 & .999 & 1.001 \\
\hline
\end{tabular}

a. Dependent Variable: BET 